\title{
Effects of Calamansi Soju and Other Alcoholic Beverages on Resin Restorations
}

\author{
Moon-Jin Jeong', Kyungwon Heo', Myoung-Hwa Lee, Myeong-Ju Jeong ${ }^{2}$, and \\ Do-Seon $\mathrm{Lim}^{3, \dagger}$ \\ ${ }^{1}$ Department of Oral Histology and Developmental Biology, School of Dentistry, Chosun University, Gwangju \\ 61452, '2Department of Biosafety, College of Life and Health, Kyungsung University, Busan 48434, ${ }^{3}$ Department \\ of Dental Hygiene, College of Health Science, Eulji University, Seongnam 13135, Korea
}

\begin{abstract}
Background: The purpose of this study was to investigate the effects of commercially available calamansi soju and other alcoholic beverages on the microhardness and erosion of resin restorations.

Methods: In this study, we evaluated the effects of Calamansi soju, Chamisul fresh, Cass fresh, and Gancia Moscato D'asti on resin restorations. Jeju Samdasoo and Coca-Cola were used as negative and positive controls, respectively. Specimens to be immersed in the beverages were manufactured using composite resin according to the product instructions. In each group, the surface microhardness was measured using a surface microhardness instrument before and after immersion for 5, 15, 30, and 60 minutes. The pattern of change in the surface of the composite resin was observed under a scanning electron microscope (SEM). Paired t-tests, one-way ANOVA, and repeated measures ANOVA were performed to compare the surface microhardness of the specimens, and the Tukey test was used as a post hoc test.

Results: The $\mathrm{pH}$ of all beverages except Jeju Samdasoo was $<5.5$, which is the critical $\mathrm{pH}$ that can induce erosion. The difference in surface microhardness of the composite resin before and after immersion for 60 minutes was significant in all groups. In particular, the largest change in surface microhardness was observed in the calamansi soju group. In the SEM analysis, loss of composite resin was observed in all groups except the Jeju Samdasoo group, and rough surfaces with pores of various sizes were observed.

Conclusion: In this study, all beverages except Jeju Samdasoo decreased the microhardness of the composite resin surface, and it was confirmed that calamansi soju had the greatest change.
\end{abstract}

Key Words: Calamansi soju, Composite resin, Microhardness, Scanning electron microscope

\section{Introduction}

Organic and natural food products have been the preferred choice of consumers recently based on health concerns ${ }^{1)}$. The reported trend also reflects the choice of products with convenience ${ }^{2}$. With such increased preference towards health-oriented and convenient food products, the demand for beverages containing various bioactive substances has increased ${ }^{3)}$.

The beverage market since 2008 has continuously increased in annual mean production. Notably, with the increased anticipation that the intake of health beverages will contribute in improving the health, the sales of fruit or vegetable beverages has increased ${ }^{4}$. In line with the trend, the recent sales of beverages containing calamansi, lemon or grapefruit with implied health benefits has increased ${ }^{5)}$, as they are viewed as having weight loss effects to increase the preference ${ }^{6}$. Among them, calamansi is a type of citrus fruits containing hesperidin and DGPP $\left(3^{\prime}, 5^{\prime}\right.$-di-C- $\beta$ glucopyranosylphloretin) that are known for antioxidation, 
anti-inflammation, anticancer and capillary protection effects $^{7}$. Moreover, calamansi shows an up to 2-fold higher level of vitamin $\mathrm{C}$ than lemon with known benefits in skin care and fatigue relief. The polyphenol component that promote antioxidation also allow calamansi to contribute to recovery from fatigue and release of toxic substances as well as in fat degradation in the body for a weight loss effect, which thus increased the popularity of calamansi beverages ${ }^{8)}$.

Calamansi is being commercialized for sales in various products from concentrates to powders, mixed beverages and alcoholic beverages. The recent trend towards consumer experience and pleasure has led to the focused interest in calamansi through the SNS. In addition, calamansi soju, made by mixing calamansi concentrate with soju, has been known among young adults as being effective in hangover removal and weight loss to increase the popularity and the consumption of calamansi in South Korea has thus increased ${ }^{9)}$. However, currently commercially available beverages are generally acidic, and it is known that the lower the $\mathrm{pH}$, the higher the possibility of causing tooth erosion. It is noteworthy that dental erosion has been reported to occur more frequently upon the intake of beverages with lower $\mathrm{pH}$ and higher acidity ${ }^{10,11)}$. In addition, a study where the $\mathrm{pH}$ levels of various commercial beverages were measured reported that the $\mathrm{pH}$ of most beverages was less than or equal to $4.0^{12)}$. In another study where the $\mathrm{pH}$ and the buffer capacity were measured for commercial fruit juices and fruit and non-fruit carbonated drinks, the fruit and non-fruit carbonated drinks showed the lowest $\mathrm{pH}$ and buffer capacity, which was reported as the cause of dental erosion and long hours of reduced $\mathrm{pH}$ in the oral cavity ${ }^{13)}$.

Meanwhile, resin-based dental restorative materials show an outstanding binding with the tooth structure and a high level of mechanical strength as well as convenient handling and outstanding aesthetics, and these benefits have led to their application in various dental clinical fields ${ }^{14)}$. However, resin-based restorative materials are significantly influenced by the changes in the environment of the oral cavity ${ }^{15)}$ and the acidic beverages or foods, in particular, could deteriorate the physical properties and cause chemical degradation because of low $\mathrm{pH}$ that has a major impact on the durability and longevity of resin restorative materials ${ }^{16)}$. Erdemir et al. ${ }^{17)}$ reported that sports drinks and energy drinks with low $\mathrm{pH}$ accelerated the decomposition process of restorative materials and shortened the longevity by reducing hardness. Yanikoğlu et al. ${ }^{18)}$ reported that the surface hardness of resin-based restorative materials could be affected by coffee, tea, acidic foods, and low $\mathrm{pH}$ beverages. In addition, Yang et al. ${ }^{19)}$, a study conducted in South Korea on four types of resin composites, reported an increase in the roughness of resin surface upon the treatment with acidic fluorine materials. Choi et al. ${ }^{20)}$ reported that the APF gel could change the surface structure of aesthetic restorative materials to create a favorable condition for bacterial growth to reduce the longevity of restorative materials. Choi et al. ${ }^{21)}$ reported that, when dental restorative materials were treated with the extracts of five selected fruits with high acidity and color, significant changes were observed on the resin surface for all five fruit extracts. In addition, Kim et al. ${ }^{14)}$, where resin composites were treated with several lactic acid fermented milk types, showed damages on the resin surface. As can be seen, previous studies have reported on the effects of some alcoholic drinks and beverages on the enamel and resin restorative materials. However, only a few studies have investigated the effects of beverages containing highly acidic extracts of fruits such as calamansi on the erosion, hardness, and longevity of dental restorative materials in comparison with other beverages.

Thus, this study prepared a selected set of alcoholic beverages including calamansi soju, a diluted mixture of calamansi concentrate with soju, and investigated their effects on the erosion and hardness of resin restorative materials. The purpose was to provide the basic data for the effective oral health care in consumers upon the intake of beverages.

\section{Materials and Methods}

\section{Materials}

For the beverages in this study, the top sales alcoholic beverages and the calamansi concentrate with a high market share in South Korea called Chanu's Calamansi 
were used. The study design included a total of six groups: Calamansi soju (calamansi concentrate+soju, prepared according to the manufacturer's guideline; Shinsung TNF, Chungnam, Korea), Chamisul fresh (soju; Hite Jinro, Seoul, Korea), Cass fresh (beer; OB beer, Seoul, Korea), and Gancia Moscato D'asti (wine; F.LLI GANCIA \& C. SPA, Asti, Italy) as the four groups of alcoholic beverages; Jeju Samdasoo ${ }^{\circledR}$ (Jeju province development Co., Jeju, Korea) as the negative control and; Coca-Cola ${ }^{\circledR}$ (CocaCola beverage Co., Yangsan, Korea) as the positive control (Table 1).

\section{Methods}

\section{1) pH and buffer capacity measurement}

To measure the $\mathrm{pH}$ of the beverages, each sample was left in room temperature $\left(25^{\circ} \mathrm{C}\right)$ for six hours, then transferred to a beaker by $50 \mathrm{ml}$. Using a pH meter (S20K pH meter; Mettler-Toledo, Greifensee, Switzerland), the $\mathrm{pH}$ of each group was measured after calibration. To measure the buffer capacity of the beverages, $0.05 \mathrm{ml}$ of $1 \mathrm{M} \mathrm{NaOH}$ was added to each sample until the $\mathrm{pH}$ reached 5.5 and 7.0, and the added amount of $1 \mathrm{M} \mathrm{NaOH}$ was measured. During the measurements, each sample was vortexed at $200 \mathrm{rpm}$ for homogenous mixing, and the mean of triplicate measurements was obtained.

\section{2) Specimen preparation}

A circular space of $5 \mathrm{~mm}$ diameter and $2 \mathrm{~mm}$ thickness was created on an acryl plate of $15 \mathrm{~mm}$ width, $10 \mathrm{~mm}$ length, and $10 \mathrm{~mm}$ thickness. The space was filled with a resin composite (Filtek ${ }^{\mathrm{TM}}$ Z350 XT; 3M ESPE, Saint Paul, MN, USA) according to the manual, and an LED light curing unit (Guilin Woodpecker Medical Instrument,
Guilin, China) was applied for 30 seconds. To flatten the specimen surface, a grinder (Struers LaboPol-5, Type 05206133; Struers, Ballerup, Denmark) was applied step-by-step with Sic-paper \#1200, \#1500, \#2000, and $\# 4000$, and a total of 180 specimens were prepared.

\section{3) Surface microhardness measurement}

In order to measure the surface hardness of the polished specimen, and before immersion in beverage, a digital microhardness tester (MMT-X7B; Matsuzawa, Akita, Japan) was positioned so that the four sides of the specimen (top, bottom, left, and right) were in a vertical direction to the stamping of the tester. After the 10 seconds of stamping at $100 \mathrm{gm}$ load, the Vickers Hardness Number (VHN) was estimated at $400 \times$ of the measuring microscope, and the mean of four sides was obtained. For each group, 24 specimens with the surface microhardness within 90 to 95 VHN range were selected; hence, a total of 144 specimens were used for the experiments.

\section{4) Specimen immersion}

Each experimental beverage was opened right before the immersion of specimen and transferred to an identical type of container by $120 \mathrm{ml}$. In each group, six specimens were immersed in beverage for 5, 15, 30, and 60 minutes.

\section{5) Surface microhardness measurement after immersion in beverage}

After 5, 15, 30, and 60 minutes of immersion in beverage, each retrieved specimen was washed with distilled water for 30 seconds, and with the digital microhardness tester, the surface microhardness was measured for the four adjacent areas as the measurement before immersion using the same method.

Table 1. Test Groups Used in the Experiment

\begin{tabular}{|c|c|c|c|}
\hline Group & Classification & Brand name & Manufacture \\
\hline Positive control & Mineral water & Jeju Samdasoo & Jeju province development Co., Jeju, Korea \\
\hline Negative control & Carbonated beverage & Coca-Cola & Coca-Cola beverage Co., Yangsan, Korea \\
\hline \multirow[t]{4}{*}{ Experiment } & Alcoholic beverages & Calamansi soju & Shinsung TNF, Chungnam, Korea \\
\hline & & Chamisul fresh & Hite Jinro, Seoul, Korea \\
\hline & & Cass fresh & OB beer, Seoul, Korea \\
\hline & & Gancia Moscato D’asti & F.LLI GANCIA \& C. SPA, Asti, Italy \\
\hline
\end{tabular}




\section{6) Scanning electron microscopy}

To examine the changes of the surface of resin composites for the control groups and the experimental groups after immersion, two specimens were randomly selected from each group. First, the specimen was dried using a critical point dryer (HCP-2; Hitachi, Tokyo, Japan). The dried specimen was fixed on the stub using a double-sided tape then covered with platinum using an ion sputter (E-1030; Hitachi) to be observed under a scanning electron microscope (SEM; S-4700; Hitachi) at 5,000× and $10 \mathrm{kV}$.

\section{7) Data analysis}

To compare the surface microhardness across the specimens in each group before immersion in beverage and 60 minutes after immersion, the paired t-test was performed. To compare the between-group differences in surface microhardness, the one-way ANOVA was used. To compare the surface microhardness depending on the time of immersion, the repeated measures ANOVA was used. For post-hoc, the Tukey test was used. All statistical analyses were performed using the SPSS 24.0 (IBM Corp., Armonk, NY, USA). The significance level was set to $\mathrm{p}<$ 0.05 .

\section{Results}

\section{1. $\mathrm{pH}$ and buffer capacity of experimental beverages}

\section{1) $\mathbf{p H}$}

Across the experimental beverages, Calamansi soju showed the lowest $\mathrm{pH}(2.93 \pm 0.01)$, and the $\mathrm{pH}$ was $3.47 \pm 0.01$ for Gancia Moscato D'asti, $4.35 \pm 0.02$ for Cass fresh, and $7.88 \pm 0.03$ for Chamisul fresh, while for the positive control Coca-Cola and the negative control Jeju Samdasoo, the $\mathrm{pH}$ was $2.45 \pm 0.01$ and $7.30 \pm 0.22$, respectively (Table 2).

\section{2) Buffer capacity}

The buffer capacity of experimental beverages at $\mathrm{pH} 5.5$ was Cass fresh 1.0 $\pm 0.0 \mathrm{ml}$, Coca-Cola $1.2 \pm 0.0 \mathrm{ml}$, Gancia Moscato D'asti $7.0 \pm 0.0 \mathrm{ml}$, and Calamansi soju $7.5 \pm 0.0$ $\mathrm{ml}$, in the order of decreasing capacity. The buffer capacity

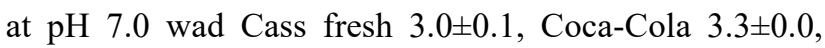
Gancia Moscato D'asti $8.5 \pm 0.1$, and Calamansi soju $10.7 \pm 0.1$, in the order of decreasing capacity (Table 2).

\section{Changes of surface microhardness after immersion in beverage}

\section{1) Time-dependent surface microhardness of resin composites}

The surface microhardness of Calamansi soju showed a significant difference between $0 \sim 5$ minutes and 30 60 minutes; 92.98 at 0 minute and 75.52 at 60 minutes. Cass fresh and Chamisul fresh showed a gradual decrease in time although no statistical significance was found. Gancia Moscato D'asti showed a significant difference in surface microhardness between $0 \sim 5$ minutes and $5 \sim 15$ minutes, with 91.81 at 0 minute. Jeju Samdasoo showed a gradual decrease in time although no statistical significance was found. Coca-Cola showed a significant difference between 0 minute (93.10) and 5 minutes

Table 2. The $\mathrm{pH}$ and Buffer Capacity of Experimental Beverages

\begin{tabular}{|c|c|c|c|c|}
\hline \multirow{2}{*}{ Classfication } & \multirow{2}{*}{ Group } & \multirow{2}{*}{ Original $\mathrm{pH}$} & \multicolumn{2}{|c|}{ Buffer capacity (ml) } \\
\hline & & & $\mathrm{pH} 5.5$ & pH 7.0 \\
\hline \multirow[t]{4}{*}{ Experiment } & Calamansi soju & $2.93 \pm 0.01$ & $7.5 \pm 0.0$ & $10.7 \pm 0.1$ \\
\hline & Chamisul fresh & $7.88 \pm 0.03$ & - & - \\
\hline & Cass fresh & $4.35 \pm 0.02$ & $1.0 \pm 0.0$ & $3.0 \pm 0.1$ \\
\hline & Gancia Moscato D'asti & $3.47 \pm 0.01$ & $7.0 \pm 0.0$ & $8.5 \pm 0.1$ \\
\hline \multirow[t]{2}{*}{ Control } & Coca-Cola & $2.45 \pm 0.01$ & $1.2 \pm 0.0$ & $3.3 \pm 0.0$ \\
\hline & Jeju Samdasoo & $7.30 \pm 0.22$ & - & - \\
\hline
\end{tabular}

Values are presented as mean \pm standard deviation. 
(86.74). The time-dependent surface microhardness did not exhibit a significant difference across the three groups (Calamansi soju, Gancia Moscato D'asti, and Coca-Cola) between 0 minute (before immersion) and 5 minutes after immersion $(\mathrm{p}>0.05$, Table 3$)$.

\section{2) Changes of surface microhardness before immersion in beverage and 60 minutes after immersion}

The variation in surface microhardness before and after immersion was the largest for Calamansi soju (17.44), followed by Cass fresh (14.09), Coca-Cola (13.22), Gancia Moscato D'asti (12.45), Chamisul fresh (6.51), and Jeju Samdasoo (5.04). The result of Tukey test showed that the surface microhardness of each group of Calamansi soju, Cass fresh, Gancia Moscato D'asti, and Coca-Cola varied significantly from that of Chamisul fresh and Jeju Samdasoo, while no significant variation in surface microhardness was found among Calamansi soju, Cass fresh, Gancia Moscato D'asti, and Coca-Cola ( $\mathrm{p}>$ 0.05 , Table 3).

Table 3. Changes in Surface Microhardness of Composite Resin Before and After Treatment according to Time in the Experimented Group

\begin{tabular}{|c|c|c|c|c|c|c|c|c|}
\hline \multirow[b]{2}{*}{ Group } & \multirow[b]{2}{*}{$\mathrm{N}$} & \multicolumn{7}{|c|}{ Time (min) } \\
\hline & & 0 & 5 & 15 & 30 & 60 & & $\begin{array}{c}0 \sim 60 \\
\text { difference }\end{array}$ \\
\hline Calamansi soju & 6 & $92.98 \pm 2.02^{\mathrm{a}}$ & $84.81 \pm 2.27^{\mathrm{b}}$ & $84.58 \pm 1.50^{\mathrm{abcd}}$ & $81.40 \pm 2.65^{\mathrm{c}}$ & $75.52 \pm 3.47^{\mathrm{d}}$ & $\mathrm{b}<\mathrm{a}, \mathrm{d}<\mathrm{c}$ & $17.44 \pm 4.45^{\mathrm{a}}$ \\
\hline Cass fresh & 6 & $93.12 \pm 1.98$ & $87.76 \pm 1.84$ & $85.65 \pm 1.79$ & $84.26 \pm 2.30$ & $79.02 \pm 4.28$ & & $14.09 \pm 3.18^{\mathrm{a}}$ \\
\hline Chamisul fresh & 6 & $91.77 \pm 2.47$ & $89.75 \pm 1.63$ & $88.21 \pm 1.68$ & $87.82 \pm 2.65$ & $85.26 \pm 2.58$ & & $6.51 \pm 3.91^{\mathrm{b}}$ \\
\hline Gancia Moscato D'asti & 6 & $91.81 \pm 2.23^{\mathrm{a}}$ & $85.48 \pm 2.64^{\mathrm{b}}$ & $81.27 \pm 4.51^{\mathrm{c}}$ & $80.59 \pm 0.57^{\mathrm{c}}$ & $79.36 \pm 1.66^{\mathrm{c}}$ & $\mathrm{b}<\mathrm{a}, \mathrm{b}<\mathrm{c}$ & $12.45 \pm 3.50^{\mathrm{a}}$ \\
\hline Jeju Samdasoo & 6 & $92.69 \pm 2.33$ & $90.11 \pm 1.25$ & $90.49 \pm 1.57$ & $89.81 \pm 1.74$ & $87.64 \pm 2.42$ & & $5.04 \pm 3.75^{\mathrm{b}}$ \\
\hline Coca-Cola & 6 & $93.10 \pm 1.94^{\mathrm{a}}$ & $86.74 \pm 1.44^{\mathrm{b}}$ & $84.70 \pm 1.26^{\mathrm{ab}}$ & $80.85 \pm 2.27^{\mathrm{ab}}$ & $79.89 \pm 2.95^{\mathrm{ab}}$ & $\mathrm{b}<\mathrm{a}$ & $13.22 \pm 2.38^{\mathrm{a}}$ \\
\hline
\end{tabular}

Values are presented as mean \pm standard deviation (unit: Vickers Hardness Number).

a,b,c The same letter indicates no significant difference by Tukey test at $\alpha=0.05$.

$\mathrm{p}<0.05$, by one-way ANOVA, repeated measures ANOVA.
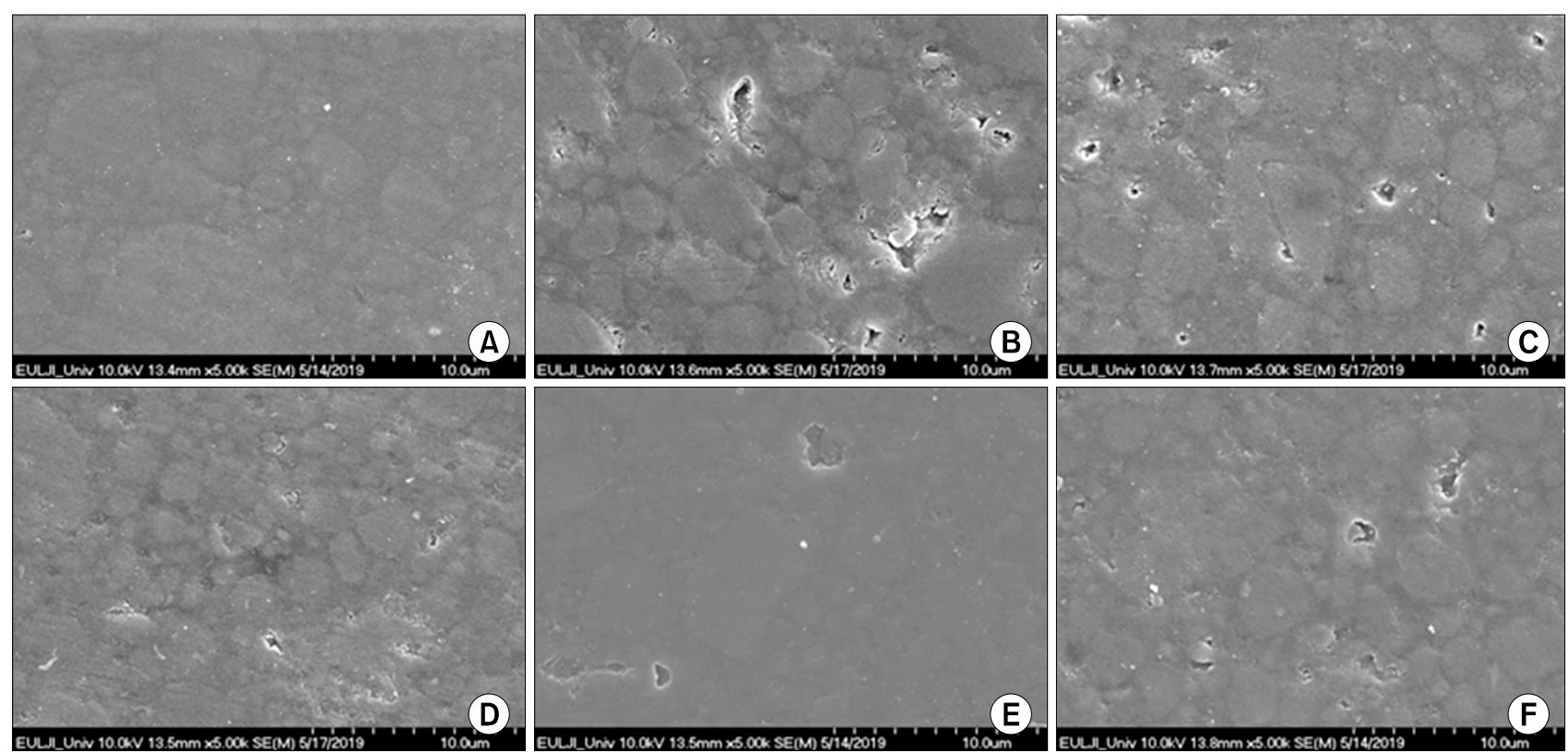

Fig. 1. Scanning electron microscope (SEM) image of composite resin surface after treatment for 60 minutes. This demineralization pattern was observed in all samples except those in the Jeju Samdasoo group. In particular, the positive control Coca-Cola showed the most severe demineralization, followed by calamansi soju and Gancia Moscato D' asti. (A) Jeju Samdasoo, (B) Coca-Cola, (C) Calamansi soju, (D) Cass fresh, (E) Chamisul fresh, (F) Gancia Moscato D' asti. All magnification is ×5,000. 


\section{Scanning electron microscopy of the resin surface after immersion in beverage}

The surface of the resin composites was observed under the SEM and all groups except Jeju Samdasoo showed a change of surface 60 minutes after immersion in beverage. The negative control Jeju Samdasoo showed smooth surface and clearly visible crystals of resin composites (Fig. 1A). The positive control Coca-Cola showed a level of degradation and loss of resin composites so that small pores of varying diameters from $1 \sim 2 \mu \mathrm{m}$ to $4 \sim 5 \mu \mathrm{m}$, with an overall rough surface patterns (Fig. 1B). On the other hand, the experimental group Calamansi soju showed a level of degradation and loss of resin composites with small pores of $1 \sim 2 \mu \mathrm{m}$ observed across the entire surface, a pattern similar to Coca-Cola (Fig. 1C). Cass fresh showed slightly rough surface and loss of resin composites with a number of small pores of $1 \mu \mathrm{m}$ (Fig. 1D). Chamisul fresh showed relatively smooth surface on the whole but with the loss of resin composites and a number of small pores of $1 \sim 2 \mu \mathrm{m}$ (Fig. 1E). Gancia Moscato D'asti also showed relatively smooth surface on the whole but with small pores of varying sizes (Fig. 1F).

\section{Discussion}

The current market has a variety of beverages, and since the 1970s, carbonated drinks such as coke and sprite have occupied the major proportion of the beverage market ${ }^{22)}$. Such drinks have shown a significant growth up to the present, and recently, fruit juices, cereal grain drinks, sports drinks, and hangover removal drinks have shown a simultaneous fast rate of growth. The recent trend of health promotion has propelled the development of a diversity of beverages in the beverage market with the change of dietary lifestyle ${ }^{23)}$. In line with such trend, the sales of beverages with an image of well-being such as those based on calamansi, lemon or grapefruit, has shown a recent increase ${ }^{5)}$, while such beverages are viewed as having hangover removal and weight loss effects to increase the preference ${ }^{6)}$. Among them, calamansi beverages have been considerably popular since 2017 , and various food products containing calamansi have attracted the interest of many consumers ${ }^{24)}$.
However, it is a well-known fact that most of the commercial beverages are acidic in nature. Choi and Shin ${ }^{12)}$ measured the acidity of beverages and reported that, with the exception of milk-based products, the $\mathrm{pH}$ of most beverages was less than or equal to 4.0 . Kim et al. ${ }^{24)}$ reported that the intake of carbonated food products, acidic foods, and citrus fruits such as tangerines ${ }^{25)}$ as well as fizzy vitamin tablets had significant effects on dental erosion $^{26)}$. Choi and $\mathrm{Shin}^{12)}$ also reported that most beverages had an acidic $\mathrm{pH}: 2.96 \pm 0.30$ for carbonated drinks, $3.29 \pm 0.37$ for fruit juices, and $3.15 \pm 0.26$ for electrolyte beverages.

In this study, likewise, the $\mathrm{pH}$ was measured for various beverages, and the lowest $\mathrm{pH}$ was shown by Calamansi soju (2.93 \pm 0.01$)$. The $\mathrm{pH}$ was $3.47 \pm 0.01$ for Gancia Moscato D'asti, 4.35 \pm 0.02 for Cass fresh, $7.88 \pm 0.03$ for Chamisul fresh, $2.45 \pm 0.01$ for the positive control Coca-Cola, and $7.30 \pm 0.22$ for the negative control Jeju Samdasoo. The $\mathrm{pH}$ of Calamansi soju in this study agreed with the reported $\mathrm{pH}$ range of $2.29 \pm 0.01$ to $2.92 \pm 0.00$ in a study on the commercially available calamansi beverages ${ }^{24)}$, and the highly acidic $\mathrm{pH}$ range of 2.56 to 2.91 in a study by Park et al. ${ }^{27)}$ on six commercial fruit liquors in South Korea. In addition, $\mathrm{Kim}^{28)}$ reported a similar result of $\mathrm{pH}$ 2.57 for Calamansi soju in the study of the effects of various blended liquors on dental erosion. Lee et al. ${ }^{29)}$ also showed that the $\mathrm{pH}$ of Calamansi soju was very low in comparison with the measured $\mathrm{pH}$ of orange juice in the range of 3.54 to 3.84 .

In Hooper et al. ${ }^{30)}$, the $\mathrm{pH}$ of the beverage as well as the buffer capacity and exposure time were shown to be the main causes of erosion. Notably, enamel dissolution was observed at $\mathrm{pH} 5.5$ or below, to indicate that the $\mathrm{pH}$ and buffer capacity were the most important chemical factors determining the level of erosion caused by acidic beverages $^{31)}$. Song and $\mathrm{Choi}^{32)}$ evaluated the level of dental erosion by various liquors in South Korea, and showed that the common soju did not cause dental erosion as it is weakly alkaline, while the low $\mathrm{pH}$ of wine containing citric acid could cause dental erosion. Park et al. $^{27)}$ also reported that various acids contained in fruit extracts in the case of liquors with the addition of fruity flavor led to an acidic $\mathrm{pH}$. In addition to fruity liquors, 
wine was also reported to show a low $\mathrm{pH}$ to require a high level of $1 \mathrm{M} \mathrm{NaOH}$ to reach the titratable acidity. The buffer capacity measured in this study at $\mathrm{pH} 5.5$ was Cass fresh 1.0 \pm 0.0 , Coca-Cola 1.2 \pm 0.0 , Gancia Moscato D'asti $7.0 \pm 0.0$, and Calamansi soju 7.5 \pm 0.0 , in the order of decreasing capacity. The buffer capacity at $\mathrm{pH} 7.0$ was Cass fresh 3.0 \pm 0.1 , Coca-Cola 3.3 \pm 0.0 , Gancia Moscato D'asti $8.5 \pm 0.1$, and Calamansi soju 10.7 \pm 0.1 , in the order of decreasing capacity. The results could be compared with Park et al. ${ }^{27)}$, where the lowest $\mathrm{pH}$ (2.56 and 2.60) was observed for liquors containing citron, which may be because calamansi is a fruit with a similar sour taste as citron. Kim's study ${ }^{28)}$ evaluating the variation in dental erosion according to the type of blended liquor, the $\mathrm{pH}$ of calamansi soju was 2.57 at a level similar to this study, while the buffer capacity was higher at 18 for $\mathrm{pH} 5.5$ and 23.5 for $\mathrm{pH}$ 7.0. This may be due to the different mixing ratio of calamansi concentrate and soju from this study.

Meanwhile, studies have reported that one of the most critical factors that reduce the performance and durability of dental restorative materials was the degradation of the restorative material on the tooth surface by foods or beverages ${ }^{16)}$. Previous studies on the effect of beverage on dental restorative materials reported that acidic drinks such as coke or juice could reduce the surface microhardness of restorative materials ${ }^{33,34)}$ while apple juice with malic acid and orange juice with citric acid had an effect on the restorative materials but distilled water did not $^{35)}$. Yanikoğlu et al. ${ }^{18)}$ reported that the effect on the surface hardness significantly varied according to the type of the restorative material and the surface treatment and immersion time, while tea, coffee and coke were shown to affect the surface hardness of resin composites. Kim ${ }^{28)}$ also reported that Calamansi soju with the lowest $\mathrm{pH}$ showed the largest variation in surface hardness depending on the time of immersion after the treatment of blended liquors.

In this study, likewise, Calamansi soju with the lowest $\mathrm{pH}$ showed the largest variation compared to the other alcoholic beverages. This is presumed to be due to the high acidity of Calamansi soju with an effect on the erosion and surface hardness of resin restorative materials. In addition, the variation was found to be the largest for
Calamansi soju, followed by Cass fresh, Gancia Moscato D'asti, and Chamisul fresh. In the comparison of surface microhardness of resin composites according to time, Calamansi soju was shown to have caused a significant difference in surface microhardness at $0 \sim 5$ minutes and $30 \sim 60$ minutes, indicating that the erosion of resin could be facilitated in time between 0 minute and 60 minutes. Notably, as the variations in the surface microhardness at the first 5 minutes and at $30 \sim 60$ minutes were the largest compared to the other alcoholic beverages, a way to minimize the exposure time of resin restorative materials to Calamansi soju should be developed.

According to Kim et al. ${ }^{24)}$, the SEM observation of bovine tooth specimens after the immersion in calamansi beverage showed that, while the surface was smooth without damage in the Jeju Samdasoo group, a rough surface was observed for the Coke, Oran-C (orange soda), and Calamansi groups, with cracks among the crystals. In this study, likewise, the surface of resin composites did not show a significant variation on the surface roughness between 0 minute and 60 minutes. But the experimental groups of Calamansi soju, Cass fresh, and Gancia Moscato D'asti showed a change in the surface towards increased roughness with small pores of varying forms as time passed. The Calamansi soju group, in particular, showed the roughest surface of the resin restorative materials with small pores of varying sizes, a pattern similar to the positive control of Coca-Cola. The phenomenon coincided with the variation in the surface microhardness before and 60 minutes after immersion in beverage, while alcoholic beverages with low $\mathrm{pH}$ were found to have affect the surface of resin restorative materials. It thus seems necessary that, upon the intake of alcoholic beverages with low $\mathrm{pH}$, a large quantity of water should be consumed. Therefore, the dilution of calamansi concentrate should lead to a lower content of calamansi than the manufacturer's guideline upon the production of calamansi soju so as to prevent dental erosion.

The results in this study collectively suggested that a set of alcoholic beverages including Calamansi soju could cause the erosion of resin composites due to low $\mathrm{pH}$. Thus, upon drinking alcoholic beverages such as Calamansi soju with low $\mathrm{pH}$, the drink should not be kept inside the oral 
cavity for a long time and water should be drunk frequently to prevent residual acidic substances. In addition, to prevent dental erosion, the frequency of acid exposure should be reduced and the time of acidic food inside the oral cavity upon intake should be restricted. In this study, other various components in alcoholic beverages could not be tested and further studies should investigate the other potential influencing factors on resin restorative materials.

\section{Notes}

\section{Conflict of interest}

No potential conflict of interest relevant to this article was reported.

\section{Ethical approval}

This article does not require for IRB screening because human origin is not used.

\section{Author contributions}

Conceptualization: Moon-Jin Jeong and Do-Seon Lim. Data acquisition: Kyungwon Heo, Myoung-Hwa Lee, and Myeong-Ju Jeong. Formal analysis: Kyungwon Heo, Myoung-Hwa Lee, and Myeong-Ju Jeong. Funding: Moon-Jin Jeong. Supervision: Do-Seon Lim. Writing-original draft: Do-Seon Lim. Writing-review \& editing: Moon-Jin Jeong and Do-Seon Lim.

\section{ORCID}

Moon-Jin Jeong, https://orcid.org/0000-0002-5547-898X Kyungwon Heo, https://orcid.org/0000-0003-0214-2216

Myoung-Hwa Lee, https://orcid.org/0000-0003-2291-5589

Myeong-Ju Jeong, https://orcid.org/0000-0001-6073-5867

Do-Seon Lim, https://orcid.org/0000-0003-4602-3323

\section{Acknowledgements}

This study was supported by research fund from Chosun University (2020).

\section{References}

1. Park HW, Nah K: Study on restaurant franchise service reflected on a single household consumer patterns: focus on
2030 generation. J Digit Des 15: 697-704, 2015.

https://doi.org/10.17280/jdd.2015.15.3.066

2. Kim ND, Jeon MY, Choi JH, et al.: Trend Korea 2020. Miraebook, Seoul, pp.383-404, 2019.

3. Lee HR, Jung BR, Park JY, et al.: Antioxidant activity and total phenolic contents of grape juice products in the Korean market. Korean J Food Preserv 15: 445-449, 2008.

4. Choi SA, Lee JH: Actual purchasing of functional beverages for adults in Chungnam area. Korean J Food Nutr 31: 520-531, 2018. https://doi.org/10.9799/ksfan.2018.31.4.520

5. Kim HN, Ko SB, Kim BS: An analysis of characteristics and trends in Korea's fruit beverage market. Korean Sanhag Gisul Haghoe Chungye Hagsul Balpyo Nonmunjib, 2019.

6. Agricultural Equipment Newspaper: Calamansi diet. Retrieved October 6, 2021, from http://www.newsam.co.kr/ news/article.html?no=25133\#0BvC(2019, November 1$)$.

7. Lou SN, Ho CT: Phenolic compounds and biological activities of small-size citrus: Kumquat and calamondin. J Food Drug Anal 25: 162-175, 2017. https://doi.org/10.1016/j.jfda.2016.10.024

8. Gradium: Calamansi benefits, side effects, how to eat, diet- God's fruit? Retrieved November 12, 2021, from: https://gradium. co.kr/calamansi-benefits/?nowprocket=1(2018, June 13).

9. Nbn TV: There are various ways to consume calamansi fruit, such as 'calamansi soju', 'clean juice', etc. Retrieved November 12, 2021, from: http://www.nbntv.co.kr/news/ articleView.html?idxno=130038(2018, November 15).

10. Van Eygen I, Vannet BV, Wehrbein H: Influence of a soft drink with low $\mathrm{pH}$ on enamel surfaces: an in vitro study. Am J Orthod Dentofacial Orthop 128: 372-377, 2005. https://doi.org/10.1016/j.ajodo.2004.03.036

11. Hughes JA, West NX, Parker DM, van den Braak MH, Addy $\mathrm{M}$ : Effects of $\mathrm{pH}$ and concentration of citric, malic and lactic acids on enamel, in vitro. J Dent 28: 147-152, 2000. https://doi.org/10.1016/s0300-5712(99)00060-3

12. Choi DY, Shin SC: A study on $\mathrm{pH}$ of several beverages in Korea. J Korean Acad Dent Health 20: 399-410, 1996.

13. Edwards M, Creanor SL, Foye RH, Gilmour WH: Buffering capacities of soft drinks: the potential influence on dental erosion. J Oral Rehabil 26: 923-927, 1999. https://doi.org/10.1046/j.1365-2842.1999.00494.x

14. Kim YS, Kim JE, Chung KH, Choi CH: Effect of fermented milk product on composite resin surface. J Korean Acad Oral 
Health 45: 138-144, 2021.

https://doi.org/10.11149/jkaoh.2021.45.3.138

15. Kwon TY: Influence of storage media on degradation of dental composite resins. Korean J Dent Mater 42: 375-383, 2015. https://doi.org/10.14815/kjdm.2015.42.4.375

16. Han L, Okamoto A, Fukushima M, Okiji T: Evaluation of flowable resin composite surfaces eroded by acidic and alcoholic drinks. Dent Mater J 27: 455-465, 2008. https://doi.org/10.4012/dmj.27.455

17. Erdemir U, Yildiz E, Eren MM, Ozel S: Surface hardness evaluation of different composite resin materials: influence of sports and energy drinks immersion after a short-term period. J Appl Oral Sci 21: 124-131, 2013. https://doi.org/10.1590/1678-7757201302185

18. Yanikoğlu N, Duymuş ZY, Yilmaz B: Effects of different solutions on the surface hardness of composite resin materials. Dent Mater J 28: 344-351, 2009. https://doi.org/10.4012/dmj.28.344

19. Yang KH, Yook GY, Choi NK, Kim SM: Effect of acidulated phosphate fluoride on the surface of composite resin. J Korean Acad Pediatr Dent 34: 255-263, 2007.

20. Choi WH, Kim EJ, Kim HJ, Kim YJ, Nam SH: The effect of $1.23 \%$ APF gel on the esthetic restorative materials. J Korean Acad Pediatr Dent 33: 281-289, 2006.

21. Choi EJ, Kim MJ, Kim MJ, et al.: Color and surface change of teeth restoration result of treatment of fruit extracts. J Digit Converg 14: 449-457, 2016. https://doi.org/10.14400/JDC.2016.14.11.449

22. Dennis EJ, Kang MJ, Han SN: Relation between beverage consumption pattern and metabolic syndrome among healthy Korean adults. Korean J Community Nutr 22: 441-455, 2017. https://doi.org/10.5720/kjen.2017.22.5.441

23. Kim DE, Kim KH, Kim AO, et al.: Effect of red vinegar drink on the surface of sound enamel. J Korean Acad Oral Health 38: 184-190, 2014. https://doi.org/10.11149/jkaoh.2014.38.3.184

24. Kim EK, Park HR, Chung KY, Choi CH, Jeong SS: Effects of some commercial calamansi-containing beverages on the enamel surface. J Korean Acad Oral Health 44: 7-12, 2020. https://doi.org/10.11149/jkaoh.2020.44.1.7

25. Johansson AK, Johansson A, Birkhed D, et al.: Dental erosion associated with soft-drink consumption in young Saudi men. Acta Odontol Scand 55: 390-397, 1997. https://doi.org/10.3109/00016359709059205

26. Jeong MJ, Lee MH, Jeong SJ, et al.: Effect of commercial effervescent vitamin tablets on bovine enamel. J Dent Hyg Sci 19: 261-270, 2019. https://doi.org/10.17135/jdhs.2019.19.4.261

27. Park SW, Kim SK, Jung EH, Kwon HK, Kim BI: Erosive potential of several fruit-flavored liquors in Korea. J Korean Dent Assoc 54: 521-528, 2016.

28. Kim YS: Difference of dental erosive potential according to the type of mixed drink. J Korea Acad-Ind Cooper Soc 21: 739-744, 2020. https://doi.org/10.5762/KAIS.2020.21.1.739

29. Lee JJ, Kim EJ, Kim JM, Yoon KY: Physicochemical properties and antioxidant activities of commercial orange juice and grapefruit juice. Korean J Food Preserv 26: 322-329, 2019. https://doi.org/10.11002/kjfp.2019.26.3.322

30. Hooper SM, Hughes JA, Newcombe RG, Addy M, West NX: A methodology for testing the erosive potential of sports drinks. J Dent 33: 343-348, 2005. https://doi.org/10.1016/j.jdent.2004.10.002

31. Barbour ME, Parker DM, Allen GC, Jandt KD: Enamel dissolution in citric acid as a function of calcium and phosphate concentrations and degree of saturation with respect to hydroxyapatite. Eur J Oral Sci 111: 428-433, 2003. https://doi.org/10.1034/j.1600-0722.2003.00059.x

32. Song AH, Choi CH: Effect of commercial alcoholic drinks on sound enamel surface of bovine teeth. J Korean Acad Oral Health 37: 180-186, 2013. https://doi.org/10.11149/jkaoh.2013.37.4.180

33. Hengtrakool C, Kukiattrakoon B, Kedjarune-Leggat U: Effect of naturally acidic agents on microhardness and surface micromorphology of restorative materials. Eur J Dent 5: 89-100, 2011. https://doi.org/10.1055/s-0039-1698863

34. Hussein TA, Bakar WZ, Ghani ZA, Mohamad D: The assessment of surface roughness and microleakage of eroded tooth-colored dental restorative materials. J Conserv Dent 17: 531-535, 2014. https://doi.org/10.4103/0972-0707.144585

35. Fatima N, Abidi SY, Qazi FU, Jat SA: Effect of different tetra pack juices on microhardness of direct tooth coloredrestorative materials. Saudi Dent J 25: 29-32, 2013. https://doi.org/10.1016/j.sdentj.2012.09.002 